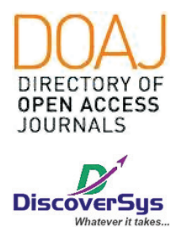

Published by DiscoverSys

\title{
Gambaran stadium dan jenis histopatologi kanker payudara di Subbagian Bedah Onkologi RSUP Sanglah Denpasar tahun 2015-2016
}

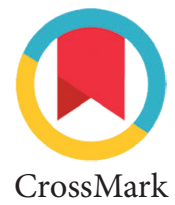

\author{
I Gde Made Satya Wangsa, ${ }{ }^{*}$ I Wayan Niryana, ${ }^{2}$ Putu Anda Tusta Adiputra, ${ }^{3}$ \\ Ni Putu Ayu Pande Arista Dewi ${ }^{4}$
}

\section{ABSTRACT}

Background: Breast cancer is a malignant neoplasm disease where in parekim tissue there is abnormal breast tissue growth that is infiltrative and destructive and can metastatic. The high incidence of breast cancer in Indonesia, is not always followed by determination of clinical staging and histopathology completely, whereas clinical staging and histopathology is needed to determine diagnosis and further management. Knowledge of the staging and histopathology is also an important indicator in determining the prognosis of breast cancer.

Methods: This research is a descriptive research with cross sectional approach, the data is obtained from medical record in Sanglah General Hospital Center with research subject of patients diagnosed with breast cancer in 2015-2016 then processed and analyzed with the help of SPSS software.

Results: Based on stage, breast cancer patients with EBC (Early Breast Cancer) stage were $30.08 \%$ with $2.95 \%$ of patients with stage I,
13.39\% stage IIA, 13.73\% stage IIB. Patients diagnosed with LABC stage (Locally Advance Breast Cancer) were 273 (47.47\%) patients with $14.78 \%, 30.95 \%$ and $1.73 \%$, respectively, of stage IIIA, IIIB and IIIC patients. In this study also recorded as many as 129 (22.43\%) patients with metastatic breast cancer (stage IV). Based on histopathology, 483 (84\%) patients with invasive ductal carcinoma, 61 (10.60\%) patients with invasive lobular carcinoma, and 31 (5.40\%) patients with other types of carcinoma.

Conclusions: Based on the results of this study found that patients diagnosed with breast cancer Sanglah Hospital in year 2015-2016 are 575 patients with the most breast cancer staging is Locally Advanced Breast Cancer (LABC) (Stage IIIA, IIIB, IIIC) with 273 (47.47\%) of patients. The most common type of breast cancer histopathology is invasive ductal carcinoma with 483 (84\%) patients

Keywords: Breast cancer, stagging, histopathology

Cite This Article: Wangsa, I.G.M.S., Niryana, I.W., Adiputra, P.A.T., Dewi, N.P.A.P.A. 2018. Gambaran stadium dan jenis histopatologi kanker payudara di Subbagian Bedah Onkologi RSUP Sanglah Denpasar tahun 2015-2016. Intisari Sains Medis 9(1): 80-84. D0I: 10.1556/ism.v9i1.165

\section{ABSTRAK}

Latar Belakang: Kanker payudara merupakan suatu penyakit neoplasma yang ganas dimana pada jaringan parekim terdapat pertumbuhan jaringan payudara abnormal yang bersifat infiltratif dan desktruktif serta dapat bermetastase. Tingginya kasus kanker payudara di Indonesia, tidak selalu diikuti oleh penentuan stadium klinis dan histopatologi secara lengkap, padahal penentuan stadium klinis dan histopatologi diperlukan untuk menentukan diagnosis dan tata laksana lebih lanjut. Pengetahuan mengenai gambaran stadium dan jenis histopatologi juga menjadi salah satu indikator penting dalam penentuan prognosis kanker payudara.

Metode: Penelitian ini merupakan penelitian deskriptif dengan pendekatan potong lintang (cross-sectional), yang datanya didapatkan dari data rekam medis di RSUP Sanglah dengan subjek penelitian pasien yang terdiagnosis kanker payudara pada tahun 2015-2016 kemudian diolah dan dianalisis dengan bantuan software SPSS.
Hasil: Berdasarkan stadium, pasien kanker payudara dengan stadium EBC (Early Breast Cancer) sebanyak 30,08\% dengan 2,95\% pasien stadium I, 13,39\% stadium IIA, 13,73\% stadium IIB. Pasien terdiagnosis dengan stadium LABC (Locally Advance Breast Cancer) berjumlah 273 (47,47\%) pasien dengan secara berturut-turut $14,78 \%, 30,95 \%$ dan 1,73\% pasien stadium IIIA, IIIB dan IIIC. Pada penelitian ini juga tercatat sebanyak 129 (22,43\%) pasien dengan kanker payudara yang sudah metastasis (stadium IV). Berdasarkan histopatologi, sebanyak 483 (84\%) pasien dengan karsinoma duktal invasif, 61(10,60\%) pasien dengan karsinoma lobular invasif, dan 31 (5,40\%) pasien dengan karsinoma tipe lain.

Simpulan: Hasil penelitian ini didapatkan bahwa pasien yang terdiagnosis kanker payudara di RSUP Sanglah pada tahun 2015-2016 sebanyak 575 pasien dengan stadium kanker payudara terbanyak adalah Locally Advance Breast Cancer (LABC) (Stadium IIIA, IIIB, IIIC) dengan jumlah $273(47,47 \%)$ pasien. Jenis histopatologi kanker payudara terbanyak adalah karsinoma duktal invasif dengan jumlah 483 (84\%) pasien.
Studi Pendidikan Dokter, Fakultas Kedokteran Universitas Udayana satyawangsa@rocketmail.com
Received: 2018-02-01

Accepted: 2018-02-21

Published: 2018-02-25
Kata kunci: Kanker payudara, stadium, histopatologi

Cite Pasal Ini: Wangsa, I.G.M.S., Niryana, I.W., Adiputra, P.A.T., Dewi, N.P.A.P.A. 2018. Gambaran stadium dan jenis histopatologi kanker payudara di Subbagian Bedah Onkologi RSUP Sanglah Denpasar tahun 2015-2016. Intisari Sains Medis 9(1): 80-84. D0I: 10.1556/ism.v9i1.165 


\section{PENDAHULUAN}

Kanker payudara merupakan suatu penyakit neoplasma yang ganas dimana pada jaringan parekim terdapat pertumbuhan jaringan payudara abnormal yang bersifat infiltratif dan desktruktif serta dapat bermetastase. Kanker payudara kebanyakan menyerang wanita, namun pria juga memiliki kemungkinan untuk menderita kanker payudara. World Health Organization (WHO) memasukkan kanker payudara ke International Classification of Diseases dengan kode nomor 174 untuk wanita dan 175 untuk pria. ${ }^{1}$

Berdasarkan American Cancer Society pada tahun 2015 terdapat 40.290 wanita meninggal kanker payudara di Amerika. Di Indonesia sendiri berdasarkan data Kementrian Kesehatan RI tahun 2016, pada tahun 2013 menunjukkan sekitar 347.792 kematian disebabkan oleh kanker. Penyakit kanker payudara merupakan penyakit kanker dengan prevalensi tertinggi di Indonesia pada tahun 2013 dengan prevalensi tertinggi pada Provinsi D.I. Yogyakarta, yaitu sebesar 2,4\% disusul Kalimantan Timur sebesar 1\% dan Provinsi Bali menempati urutan ke 10 sebesar $0.6 \%$. Berdasarkan estimasi, jumlah penderita kanker payudara terbanyak terdapat pada Provinsi Jawa Tengah sebesar 11.511 penderita, Provinsi Jawa Timur sebesar 9.688 penderita dan Provinsi Bali menempati urutan ke 13 dengan 1.233 penderita. ${ }^{2}$

Tingginya kasus kanker payudara di Indonesia, tidak selalu diikuti oleh penentuan stadium klinis dan histopatologi secara lengkap, padahal penentuan stadium klinis dan histopatologi diperlukan untuk menentukan diagnosis dan tata laksana lebih lanjut. Pengetahuan mengenai gambaran stadium dan jenis histopatologi juga menjadi salah satu indikator penting dalam penentuan prognosis kanker payudara.

Ada beberapa metode yang digunakan untuk mendiagnosis kanker payudara. Sampai saat ini yang menjadi gold standard untuk mendiagnosis kanker payudara adalah pemeriksaan histopatologi. Pemeriksaan histopatologi dapat menentukan jenis kanker payudara. Prosedur pemeriksaan histopatologi adalah pasien harus dilakukan biopsi. Hasil biopsi dapat digunakan sebagai diagnosis kanker payudara dan juga pemantauan keberhasilan terapi. Gambaran histopatologi yang dimaksud berupa morfologi jaringan kanker secara mikroskopis dari patologi anatomi yang merupakan parameter penting dan gold standard. ${ }^{3,4}$ Berdasarkan hal tersebut peneliti tertarik untuk melakukan penelitian tentang gambaran stadium dan jenis histopatologi kanker payudara di subbagian bedah onkologi RSUP Sanglah tahun 2015-2016.

\section{METODE}

Penelitian ini merupakan penelitian deskriptif dengan pendekatan potong lintang (cross-sectional) yang dilaksanakan di RSUP Sanglah Denpasar, di subbagian bedah onkologi dengan teknik penentuan sampel menggunakan metode total sampling. Adapun yang akan diteliti dalam penelitian ini adalah berdasarkan stadium, dimana stadium IA, IB, IIA, IIB yang dikategorikan sebagai Early Breast Cancer (EBC), stadium IIIA, IIIB, IIIC dikategorikan sebagai Locally Advance Breast Cancer (LABC), sedangkan stadium IV termasuk ke dalam kategori Metastatic Breast Cancer (MBC). Berdasarkan histopatologi dibagi menjadi dua kelompok, yaitu Karsinoma Non invasif (Karsinoma duktal invasif, Karsinoma lobular invasif) dan Karsinoma Invasif (Invasive ductal carcinoma, Invasive Ductal Carcinoma with Paget Disease, Infiltrating lobular carcinoma, Mucinous Carcinoma, Medullary carcinoma, Papillary carcinoma, Tubular carcinoma, Adenoid cystic carcinoma, Secretory carcinoma (juvenile), Carcinoma Apocrine, Cribriform Carcinoma, Carcinoma with Metaplasia, Squamous Carcinoma, Inflammatory Carcinoma).

Data yang didapatkan berasal dari data rekam medis di RSUP Sanglah yang berupa data sekunder dengan subjek penelitian pasien yang terdiagnosis kanker payudara pada tahun 2015-2016 yang memenuhi kriteria inklusi (Semua pasien kanker payudara yang sudah terdiagnosis kanker payudara di subbagian bedah onkologi RSUP sanglah tahun 2015-2016) dan eksklusi (Pasien kanker payudara dengan catatan rekam medis yang tidak lengkap), kemudian diolah dan dianalisis dengan bantuan software SPSS.

\section{HASIL}

Jumlah seluruh pasien kanker payudara pada penelitian ini adalah 575 pasien, sebanyak 36 pasien dieksklusi pada penelitian karena tidak sesuai dengan kriteria inklusi (RM kurang lengkap). Sebanyak 253 (44\%) pasien terdiagnosis kanker payudara di RSUP Sanglah pada tahun 2015 dan 322 pasien (56\%) pada tahun 2016. Pada penelitian ini dominan merupakan pasien perempuan $99,65 \%$ sedangkan laki-laki hanya sekitar $0,35 \%$. Rerata usia pasien adalah 48,85 \pm 9 , 46 tahun dengan puncak usia terbanyak 44 \pm 9 , 46 tahun. Pasien lebih banyak berusia $>40$ tahun, yaitu dengan jumlah

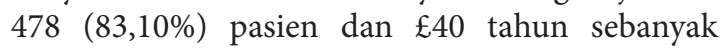
97 (6,90\%) pasien. Berdasarkan stadium, pasien kanker payudara dengan stadium EBC (Early Breast Cancer) sebanyak 30,08\% dengan 2,95\% pasien stadium I, $13,39 \%$ stadium IIA, 13,73\% 
Tabel 1 Karakteristik pasien kanker payudara di RSUP Sanglah tahun 2015-2016

\begin{tabular}{|c|c|c|}
\hline Variabel & n (\%) & SD \\
\hline \multicolumn{3}{|l|}{ Tahun } \\
\hline 2015 & $253(44,00)$ & \\
\hline 2016 & $322(56,00)$ & \\
\hline Total & $575(100,00)$ & \\
\hline \multicolumn{3}{|l|}{ Jenis Kelamin } \\
\hline Perempuan & $573(99,65)$ & \\
\hline Laki - Laki & $2(0,35)$ & \\
\hline \multicolumn{3}{|l|}{ Umur } \\
\hline Rerata & & $48,84 \pm 9,46$ \\
\hline Median & & $48,00 \pm 9,46$ \\
\hline Modus & & $44,00 \pm 9,46$ \\
\hline Umur terendah & & 23 \\
\hline Umur Tertinggi & & 79 \\
\hline \multicolumn{3}{|l|}{ Kelompok Umur } \\
\hline 1 - 40 Tahun & $97(16,90)$ & \\
\hline$>40$ Tahun & $478(83,10)$ & \\
\hline \multicolumn{3}{|l|}{ Stadium } \\
\hline Early Breast Cancer (EBC) & $173(30,08)$ & \\
\hline I & $17(2,95)$ & \\
\hline IIA & $77(13,39)$ & \\
\hline IIB & $79(13,73)$ & \\
\hline Locally Advance Breast Cancer (LABC) & $273(47,47)$ & \\
\hline IIIA & $85(14,78)$ & \\
\hline IIIB & $178(30,95)$ & \\
\hline IIIC & $10(1,73)$ & \\
\hline Metastatic Breast Cancer (MBC) & $129(22,43)$ & \\
\hline IV & $129(22,43)$ & \\
\hline \multicolumn{3}{|l|}{ Histopatologi } \\
\hline Karsinoma duktal invasif & $483(84,00)$ & \\
\hline Karsinoma lobular invasif & $61(10,60)$ & \\
\hline Karsinoma tipe lain & $31(5,40)$ & \\
\hline
\end{tabular}

Keterangan: $\mathrm{SD}=$ Standar Deviasi

Tabel 2 Kejadian angka kanker payudara berdasarkan kelompok umur pada tahun 2015-2016

\begin{tabular}{lcc}
\hline & \multicolumn{2}{c}{ Kelompok Umur } \\
\cline { 2 - 3 } Tahun & $\begin{array}{c}\mathbf{1 - 4 0} \text { Tahun } \\
\mathbf{n}(\%)\end{array}$ & $\begin{array}{c}\mathbf{4 0} \text { Tahun } \\
\mathbf{n}(\%)\end{array}$ \\
\hline 2015 & $41(16,20)$ & $212(83,80)$ \\
2016 & $56(17,40)$ & $266(82,60)$ \\
\hline
\end{tabular}

Tabel 3 Proporsi gambaran stadium kanker payudara di RS Sanglah pada tahun 2015-2016

\begin{tabular}{lccc}
\hline & \multicolumn{3}{c}{ Stadium } \\
\cline { 2 - 4 } Tahun & $\begin{array}{c}\text { EBC } \\
\mathbf{n}(\%)\end{array}$ & $\begin{array}{c}\text { LABC } \\
\mathbf{n}(\%)\end{array}$ & $\begin{array}{c}\text { MBC } \\
\mathbf{n}(\%)\end{array}$ \\
\hline 2015 & $66(26,08)$ & $129(51,00)$ & $58(22,92)$ \\
2016 & $107(33,22)$ & $144(44,74)$ & $71(22,04)$ \\
\hline
\end{tabular}

stadium IIB. Pasien terdiagnosis dengan stadium LABC (Locally Advance Breast Cancer) berjumlah $273(47,47 \%)$ pasien dengan secara berturut-turut $14,78 \%, 30,95 \%$ dan $1,73 \%$ pasien stadium IIIA, IIIB dan IIIC. Pada penelitian ini juga tercatat sebanyak $129(22,43 \%)$ pasien dengan kanker payudara yang sudah metastasis (stadium IV). Berdasarkan histopatologi, sebanyak 483 (84\%) pasien dengan karsinoma duktal invasif, $61(10,60 \%)$ pasien dengan karsinoma lobular invasif, dan 31 (5,40\%) pasien dengan karsinoma tipe lain (Tabel 1).

Pasien kanker payudara di RSUP Sanglah pada tahun 2015 sebanyak $83,80 \%$ berusia $>40$ tahun dan $16,20 \%$ berusia $£ 40$ tahun. Hal yang sama juga didapatkan pada tahun 2016 dimana pasien lebih banyak berusia $>40$ tahun $(82,60 \%)$ sedangkan hanya $17,40 \%$ yang berusia $£ 40$ tahun (Tabel 2).

Pada tahun 2015 kecenderungan pasien terdiagnosis dengan stadium LABC $51,00 \%$, sedangkan EBC, MBC sebanyak 26,08\%, 22,92\% secara berturut-turut. Pada tahun 2016 juga didapatkan data yang sama yaitu dengan diagnosis LABC menempati angka paling tinggi sebanyak 44,74\% pasien, EBC sebanyak $33,22 \%$, dan MBC sebanyak $22,04 \%$ pasien (Tabel 3).

Berdasarkan kelompok usia maka dari seluruh pasien yang berusia $£ 40$ tahun (97 pasien), jumlah pasien yang terdiagnosis dengan stadium kelompok LABC menempati jumlah terbanyak yaitu 46,39\%, selanjutnya EBC sebanyak 29,90\%, dan 23,71\% merupakan $\mathrm{MBC}$, sedangkan dari 478 pasien yang berusia $>40$ tahun juga demikian, LABC sebanyak 47,69\%, kemudian dilanjutkan dengan EBC sebanyak $30,12 \%$, sedangkan MBC hanya 22,17\% (Tabel 4).

Dari 253 pasien pada tahun 2015, gambaran histologi karsinoma duktal invasif menempati angka tertinggi, yaitu sebanyak $84,58 \%$ dan pada tahun 2016 sebanyak 83,54\%. Gambaran histopatologi karsinoma lobular invasif pada tahun 2015 sebanyak 9,10\% dan karsinoma tipe lain sebanyak 6,32\% dari 253 pasien. Pada tahun 2016 dari 322 pasien $11,81 \%$ dengan gambaran histopatologi karsinoma lobular invasif, dan 4,65\% merupakan karsinoma tipe lain (Tabel 5).

Gambaran histopatologi berdasarkan kelompok usia bisa dilihat pada (table 6). kelompok pada usia $£ 40$ tahun karsinoma duktal invasif merupakan gambaran histopatologi terbanyak, begitu halnya juga ditemukan pada kelompok usia $>40$ tahun (83,05\%). Pada kelompok usia $£ 40$ lebih banyak pasien dengan gambaran histopatologi karsinoma tipe lain $(7,21 \%)$ dibandingkan dengan karsinoma lobular invasif $(4,12 \%)$ sedangkan pada kelompok 
Tabel 4 Proporsi gambaran stadium kanker payudara berdasarkan kelompok umur di RSUP Sanglah pada tahun 2015-2016

\begin{tabular}{lccc}
\hline & \multicolumn{3}{c}{ Stadium } \\
\cline { 2 - 4 } Kelompok & EBC & LABC & MBC \\
Umur & $\mathbf{n}(\%)$ & $\mathbf{n}(\%)$ & $\mathbf{n}(\%)$ \\
\hline $1-40$ Tahun & $29(29,90)$ & $45(46,39)$ & $23(23,71)$ \\
$>40$ Tahun & $144(30,12)$ & $228(47,69)$ & $106(22,17)$ \\
\hline
\end{tabular}

Tabel 5 Jenis histopatologi kanker payudara di RSUP Sanglah pada tahun 2015-2016

\begin{tabular}{lccc}
\hline Tahun & $\begin{array}{c}\text { Karsinoma duktal } \\
\text { invasive } \mathbf{n}(\%)\end{array}$ & $\begin{array}{c}\text { Karsinoma lobular } \\
\text { invasive } \mathbf{n}(\%)\end{array}$ & $\begin{array}{c}\text { Karsinoma tipe } \\
\text { lain } \mathbf{n}(\%)\end{array}$ \\
\hline 2015 & $214(84,58)$ & $23(9,10)$ & $16(6,32)$ \\
2016 & $269(83,54)$ & $38(11,81)$ & $15(4,65)$ \\
\hline
\end{tabular}

Tabel 6 Proporsi jenis histopatologi berdasarkan kelompok umur pada kanker payudara di RSUP Sanglah pada tahun 2015-2016

\begin{tabular}{lccc}
\hline \multirow{2}{*}{$\begin{array}{l}\text { Kelompok } \\
\text { Umur }\end{array}$} & $\begin{array}{c}\text { Karsino-ma duktal } \\
\text { invasive } \mathbf{n}(\%)\end{array}$ & $\begin{array}{c}\text { Karsino-ma lobular } \\
\text { invasive } \mathbf{n}(\%)\end{array}$ & $\begin{array}{c}\text { Karsinoma } \\
\text { tipe lain } \mathbf{n}(\%)\end{array}$ \\
\hline 1 - 40 Tahun & $86(88,65)$ & $4(4,12)$ & $7(7,23)$ \\
$>40$ Tahun & $397(83,05)$ & $57(11,92)$ & $24(5,03)$ \\
\hline
\end{tabular}

Tabel 7 Proporsi jenis histopatologi berdasarkan stadium pada pasien kanker payudara di RSUP Sanglah pada tahun 2015-2016

\begin{tabular}{lccc}
\hline & \multicolumn{3}{c}{ Histopatologi } \\
\cline { 2 - 4 } Stadium & $\begin{array}{c}\text { Karsinoma duktal } \\
\text { invasive } \mathbf{n}(\%)\end{array}$ & $\begin{array}{c}\text { Karsinoma lobular } \\
\text { invasive } \mathbf{n}(\%)\end{array}$ & $\begin{array}{c}\text { Karsinoma tipe } \\
\text { lain } \mathbf{n}(\%)\end{array}$ \\
\hline EBC & $137(79,19)$ & $26(15,02)$ & $10(5,79)$ \\
LABC & $242(88,64)$ & $19(6,95)$ & $12(4,41)$ \\
MBC & $104(80,62)$ & $16(12,40)$ & $9(6,98)$ \\
\hline
\end{tabular}

usia $>40$ tahun lebih banyak karsinoma lobular invasif $(11,92 \%)$ dibandingkan dengan karsinoma tipe lain (5,03\%) (Tabel 6).

Dari seluruh pasien dengan stadium EBC (79,19\%), LABC (88,64\%), dan MBC (80,62\%) memiliki gambaran histopatologi karsinoma duktal invasif, dengan demikian maka dari seluruh pasien pada penelitian ini gambaran histopatologi karsinoma duktal invasif menempati gambaran histopatologi terbanyak (Tabel 7) diikuti oleh karsinoma lobular invasif, yaitu pada EBC $(15,02 \%)$, LABC $(6,95 \%)$ dan MBC $(12,40 \%)$. Lalu karsinoma tipe lain, yaitu pada EBC (5,79\%), LABC $(4,41 \%)$, MBC (6,98\%) (Tabel 7).

\section{DISKUSI}

\section{Proporsi Gambaran Stadium EBC, LABC, MBC pada Kanker Payudara}

Pada penelitian ini didapatkan proporsi kelompok stadium EBC sebesar 30,08\% dengan stadium I (2,95\%), stadium IIA (13,39\%), dan IIB $(13,73 \%)$, sedangkan proporsi LABC sebesar $47,47 \%$ dengan data terbanyak proporsi stadium pada IIIB (30,95\%) dan MBC (stadium IV) sebesar 22,43\%. Hasil penelitian ini berbeda dengan hasil penelitian dari Phuong Dung, dkk yaitu di dapatkan proporsi stadium 0 -I yaitu $14,7 \%$, dan tingginya proporsi angka kejadian payudara pada stadium II $(62,2 \%)$ sedangkan stadium III dan IV hanya $27,6 \%{ }^{5}$ Penelitian di Amerika Serikat mendapatkan 58,6\% pasien di diagnosis pada stadium I. ${ }^{6}$ Perbedaan ini kemungkinan karena deteksi kanker payudara lebih awal dan kesadaran pasien tinggi terhadap tingkat kesehatannya.

Penelitian yang mendukung hasil ini adalah penelitian di Asia Tenggara dimana $>50 \%$ pasien kanker payudara di Asia Tenggara didiagnosis dengan stadium III atau stadium IV, kecuali di Singapura 69\% merupakan stadium awal. ${ }^{7}$ Di Filipina 53\% kanker payudara terdeteksi pada stadium III dan IV dan hanya 2-3\% stadium I. ${ }^{8,9}$ Di Indonesia dan Thailand proporsi wanita yang terdiagnosis kanker payudara pada stadium akhir sebanyak 45\%-55\%. ${ }^{10}$ Tingginya proporsi stadium lanjut pada penelitian ini karena kurangnya kesadaran mengenai kesehatan payudara dan kurangnya program deteksi awal sehingga outcome dari penanganan akan semakin buruk.

Jika dilihat dari segi proporsi stadium berdasarkan umur maka proporsi tertinggi adalah kelompok LABC (stadium IIIA, IIIB, IIIC), yaitu 46,39\% diantara usia $£ 40$ tahun dan $47,67 \%$ diantara usia $>40$ tahun, hal ini menunjukkan walapun usia muda dan tua pasien pada populasi ini memiliki kesadaran yang rendah terhadap kanker payudara dan rendahnya kesadaran untuk mencari penanganan lebih lanjut ke rumah sakit. ${ }^{11}$

\section{Proporsi Jenis Histopatologi pada Kanker Payudara}

Penelitian di RSUP Sanglah pada tahun 2015-2016 mendapatkan hasil gambaran histopatologi terbanyak yaitu karsinoma duktal invasif sebesar $84 \%$, diikuti oleh karsinoma lobar invasif sebesar 10,60\% dan karsinoma tipe lain (5,40\%). Penelitian yang sama di Malaysia juga menunjukan hal serupa yaitu dengan gambaran karsinoma duktal invasif sebesar 89,7\% dan karsinoma lobular invasif sebesar 3\%. ${ }^{12}$ Penelitian ini serupa dengan penelitian oleh Aizhan 
Abiltayeva, dkk dimana proporsi karsinoma duktal invasif sebesar $72,7 \%$, tipe lobular $13,4 \%$, dan tipe lain $13,8 \% .^{13}$

Pada penelitian ini di dapatkan proporsi karsinoma duktal invasif tertinggi diantara tipe histopatologi lainnya dengan $88,65 \%$ diantara usia $£ 40$ tahun dan $83,05 \%$ pada usia $>40$ tahun, hasil penelitian ini sejalan dengan penelitian Abdulkader Albasari, dkk dengan proporsi karsinoma duktal invasif pada usia $>40$ sebesar $69,37 \%$ dan proporsi karsinoma lobular invasif sebesar 2,87\% sedangkan pada usia $£ 40$ tahun ditemukan hanya $19,37 \%$ dan tidak ditemukan pasien dengan tipe karsinoma lobular invasif pada kelompok usia $£ 40$ tahun (0\%). ${ }^{14}$ Hal ini karena pada penelitian ini juga ditemukan pasien kanker payudara sebesar $>50 \%$ merupakan stadium III.

Proporsi pasien dengan karsinoma duktal invasif pada kelompok EBC (stadium I dan II) di penelitian ini sebesar 79,19\% dan pada kelompok LABC $(88,64 \%)$ dan MBC sebesar 80,62\%, dimana menunjukan proporsi karsinoma duktal invasif merupakan tipe histopatologi terbanyak dari masing-masing kelompok stadium. Pada penelitian yang dilakukan oleh EY Tan, dkk menunjukan hal yang berbeda dimana proporsi karsinoma duktal invasif tertinggi pada kelompok EBC sebesar 87,5\% sedangkan pada kelompok LABC atau MBC sebesar $86,0 \%$ hal ini karena proporsi stadium lebih banyak pada stadium II sedangkan pada penelitian ini lebih banyak proporsi stadium III dan IV. ${ }^{11}$

\section{KETERBATASAN}

Kurangnya data pasien dengan stadium 0 dan gambaran tipe histopatologi insitu dikarenakan tidak lengkapnya data pada pasien stadium awal sehingga data menjadi ter-eksklusi di penelitian ini atau kemungkinan karena memang sedikitnya pasien dengan stadium awal pada populasi penelitian ini. Oleh karena itu dipandang perlu untuk melakukan pendataan yang lebih baik dan lengkap sehingga hasil penelitian menjadi lebih akurat.

\section{SIMPULAN}

Pada penelitian ini, didapatkan bahwa pasien yang terdiagnosis kanker payudara di RSUP Sanglah pada tahun 2015-2016 sebanyak 575 pasien dengan Stadium kanker payudara terbanyak adalah Locally Advance Breast Cancer (LABC) (Stadium IIIA, IIIB, IIIC) dengan jumlah 273 pasien. Jenis histopatologi kanker payudara terbanyak adalah karsinoma duktal invasif dengan jumlah 483 pasien.

\section{DAFTAR PUSTAKA}

1. Tavassoli, F. a, Schnitt, S. J., Hoefler, H., Boecker, W., Rosai, J., Heywang-Kobrunner, S. H., ... Lakhani SR. Intraductal proliferative lesions. World Health Organization Classification of Tumours. Pathology and Genetics of Tumours of the Breast and Female Genital Organs. 5th ed. Paul Kleihhues LHS, editor. Lyon: IAARC; 2003. 63-74 p.

2. RI DK. Bulan Peduli kanker Payudara. InfoDatin. Jakarta Selatan; 2016. 1-9 p.

3. Kwok TC, Rakha EA, Lee AHS, Grainge M, Green AR, Ellis IO, et al. Histological grading of breast cancer on needle core biopsy: The role of immunohistochemical assessment of proliferation. Histopathology. 2010;57(2):212-9.

4. Nigam M, Nigam B. Triple Assessment of Breast - Gold Standard in Mass Screening for Breast Cancer Diagnosis. Iosr-Jdms. 2013;7(3):1-7.

5. Dung P, Trieu Y, Mello-thoms C, Brennan PC. Female breast cancer in Vietnam : a comparison across Asian specific regions. Cancer Biol Med. 2015;12:238-45.

6. J S. Patterns of Breast Cancer Presentation in the United Sates. Am Surg. 2009;75(9):545-9.

7. MC Theo KS. Camcer Trends and Incidences in Singapore. Jpn J Clin Oncol. 2013;43:219-24.

8. ML De leon Matsuda AL. BRCA1 and BRCA2 Mutatioins among Breast. Int J Cancer. 2002;98:596-603.

9. CA Ngelangel E wang. Cancer and the Philipines Cancer Control Program. Jpn J Clin Oncol. 2002;32:52-61.

10. T Aryandono H. Survival from Operable Breast Cancer: Prognostic Factor in Yogyakarta, Indonesia. Asian Pacific J Cancer. 2006;7:455-9.

11. Tan EY, Edin M, Surg MM, Wong HB, Ang BK, Edin F, et al. Locally Advanced and Metastatic Breast Cancer in a Tertiary Hospital. Ann Acad Med. 2010;34(10):595-601.

12. Ibrahim NI, Dahlui M, Aina EN. Who are the Breast Cancer Survivors in Malaysia? Who are the Breast Cancer Survivors in Malaysia? Asian Pacific J Cancer. 2014;13(January):2213-8.

13. Abiltayeva A, Moore MA, Myssayev A, Adylkhanov T, Baissalbayeva A, Zhabagin $\mathrm{K}$, et al. Clinical , Histopathological and Molecular Characteristics of Metastatic Breast Cancer in North-Eastern Kazakhstan : a 10 Year Retrospective Study. Asian Pacific J Cancer. 2016;17:4797-802.

14. Abdulkader Albasri ASH. Histopathological features of breast cancer in Al-Madinah region of Saudi Arabia. Saudi Med J. 2014;35(12):1489-93.

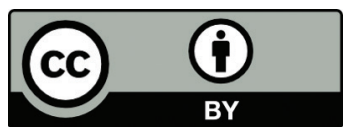

This work is licensed under a Creative Commons Attribution 